\title{
Combining Tools from Edge-of-Field to In-Stream to Attenuate Reactive Nitrogen along Small Agricultural Waterways
}

\author{
Brandon C. Goeller ${ }^{1,2, * \mathbb{C}}$, Catherine M. Febria ${ }^{2,3}{ }^{\mathbb{D}}$, Lucy A. McKergow ${ }^{1}$, Jon S. Harding ${ }^{2}$, \\ Fleur E. Matheson ${ }^{1}$, Chris C. Tanner ${ }^{1}$ and Angus R. McIntosh ${ }^{2}$ \\ 1 National Institute of Water and Atmospheric Research Limited (NIWA), Hamilton 3216, New Zealand; \\ lucy.mckergow@niwa.co.nz (L.A.M.); fleur.matheson@niwa.co.nz (F.E.M.); chris.tanner@niwa.co.nz (C.C.T.) \\ 2 School of Biological Sciences, University of Canterbury, Christchurch 8140, New Zealand; \\ jon.harding@canterbury.ac.nz (J.S.H.); angus.mcintosh@canterbury.ac.nz (A.R.M.) \\ 3 University of Windsor, Great Lakes Institute for Environmental Research (GLIER), Windsor, Ontario N9C \\ 1A2, Canada; catherine.febria@uwindsor.ca \\ * Correspondence: brandon.goeller@niwa.co.nz; Tel.: +64-7-838-8361
}

Received: 1 December 2019; Accepted: 27 January 2020; Published: 31 January 2020

\begin{abstract}
Reducing excessive reactive nitrogen $(\mathrm{N})$ in agricultural waterways is a major challenge for freshwater managers and landowners. Effective solutions require the use of multiple and combined $\mathrm{N}$ attenuation tools, targeted along small ditches and streams. We present a visual framework to guide novel applications of 'tool stacking' that include edge-of-field and waterway-based options targeting $\mathrm{N}$ delivery pathways, timing, and impacts in the receiving environment (i.e., changes in concentration or load). Implementing tools at multiple locations and scales using a 'toolbox' approach will better leverage key hydrological and biogeochemical processes for $\mathrm{N}$ attenuation (e.g., water retention, infiltration and filtering, contact with organic soils and microbes, and denitrification), in addition to enhancing ecological benefits to waterways. Our framework applies primarily to temperate or warmer climates, since cold temperatures and freeze-thaw-related processes limit biologically mediated $\mathrm{N}$ attenuation in cold climates. Moreover, we encourage scientists and managers to codevelop $\mathrm{N}$ attenuation toolboxes with farmers, since implementation will require tailored fits to local hydrological, social, and productive landscapes. Generating further knowledge around N attenuation tool stacking in different climates and landscape contexts will advance management actions to attenuate agricultural catchment $\mathrm{N}$. Understanding how different tools can be best combined to target key contaminant transport pathways and create activated zones of attenuation along and within small agricultural waterways will be essential.
\end{abstract}

Keywords: agricultural drainage ditch; denitrifying bioreactor; catchment management; nitrate-nitrogen; precision conservation; riparian buffer; stream rehabilitation

\section{Introduction}

Nutrient pollution from agricultural land use has degraded water quality and aquatic ecosystem health, creating significant management challenges for aquatic ecosystems around the world [1,2]. Excess reactive nitrogen $(\mathrm{N})$ and phosphorus $(\mathrm{P})$ inputs can cause eutrophication, toxic algal blooms, anoxic dead zones, altered food webs in receiving freshwater and estuarine environments, and nitrate toxicity in groundwater [2-4]. Small agricultural streams and ditches are the beginning of drainage systems that receive and transport excess nutrients to larger downstream waterways [5,6]. Managing $\mathrm{N}$ is particularly challenging due to the high mobility of $\mathrm{N}$ lost from the soil/plant system and the general importance of diffuse versus point sources [7,8]. While land-based nutrient reduction strategies have 
long been the focus of efforts to curb $\mathrm{N}$ loss from agricultural landscapes $[9,10]$, in-field practices like $\mathrm{N}$ management and cover crops will not singly or together meet catchment water quality goals [11,12]. Nevertheless, holistic targeting of the hydrological and biogeochemical processes involved in $\mathrm{N}$ transport and attenuation has been challenging to achieve in practice [13]. Moreover, $\mathrm{N}$ attenuation practices are frequently implemented in isolation for single fields or farms and not in a targeted approach at the catchment scale [12], despite a clear need to manage $\mathrm{N}$ at the farm and catchment scales. Therefore, to reduce $\mathrm{N}$ export, in-field practices likely need to be combined with multiple tools located along terrestrial and aquatic interfaces, and within receiving waterways [14-16]. Nevertheless, despite promising modeled $\mathrm{N}$ export reductions by combining in-stream options with land-based $\mathrm{N}$ management and attenuation [15], 'tool stacking' from the edge-of-field to in-stream has not yet been evaluated in situ at the catchment scale.

We evaluate the challenges and opportunities for codeveloping tool stacking approaches to attenuate excess $\mathrm{N}$ from edge-of-field to in-stream environments along small, agricultural waterways. To enhance the success of multiple-scale $\mathrm{N}$ attenuation, we support the adoption of tool stacking that targets the 'right practice at the right place' (RPRP) [12]. Our definition of small waterways encompasses ephemerally or intermittently flowing channels to permanently inundated second-order ditches and streams that are more likely to intercept local rather than regional groundwater [17]. The RPRP framework enables conservation planners to identify locations where tool stacking or 'treatment trains' consisting of multiple tools $[16,18,19]$ can be implemented along the various flow pathways in a catchment to maximize water quality improvements. In practice, however, the links between field-scale variability in $\mathrm{N}$ export (i.e., hydrological delivery pathways and timing) and $\mathrm{N}$ attenuation at the catchment scale are difficult to establish. Therefore, identifying and managing the drivers of $\mathrm{N}$ export and the impacts on the receiving environment could improve the outcomes of local solutions adopted from landscape-scale frameworks such as RPRP.

We present a visual framework to guide novel applications of tool stacking that include waterway-based options, based on $\mathrm{N}$ delivery pathways, timing, and impacts in the receiving environment (i.e., changes in concentration or load). The framework was developed for practitioners and researchers alike to address the most common and pervasive challenges to reducing excessive $\mathrm{N}$ along small agricultural waterways. Knowledge has been synthesized from a broad range of published and grey literature, field-based implementations, and research experiences. Our recommended approach emphasizes accommodating system variability, which entails fitting the hydrological landscape, including temporal and spatial inequality in $\mathrm{N}$ export, as well as working within the social and productive landscapes at a scale that makes a difference and at the most strategic locations along small waterways. Specifically, we focus on the importance of:

1. managing small waterways to elicit effective change in the receiving environment,

2. targeting local $\mathrm{N}$ export dynamics and underlying hydrological variability from agricultural land to waterways, and

3. overcoming factors limiting $\mathrm{N}$ attenuation with suites of edge-of-field to waterway-based tools at multiple scales and locations. We also emphasize the need to

4. encourage codevelopment of novel, effective, multiple-tool, multiple-scale waterway $\mathrm{N}$ attenuation approaches by scientists, practitioners, and farming communities to overcome the technical and practical challenges to managing $\mathrm{N}$ in agricultural landscapes.

\section{Understanding and Managing for N Export Variability along Small Waterways}

Focusing $\mathrm{N}$ attenuation actions along small waterways is likely to have the greatest effect on improving water quality at regional scales $[12,20]$. However, designing effectual management of these systems requires better ways to account for variability in nutrient attenuation and export across multiple scales [21-23]. By targeting the sources and locations where $\mathrm{N}$ can be most effectively dealt with, small waterways are especially important for influencing nutrient cycling via assimilation and denitrification [24,25]. However, active management is often required to rehabilitate the intrinsic 
ability of small, agricultural streams and ditches to process nutrients [26-28]. This is because channel clearance and drainage provision supersede establishing natural in-channel features to retain and cycle organic matter and nutrients [29,30]. The responsiveness of these small waterways to $\mathrm{N}$ management actions [24], as well as the disproportionate abundance and influence of headwaters on water quality and ecosystem processes at larger spatial scales [31,32], makes $\mathrm{N}$ attenuation along small waterways a promising management approach.

Dynamic patterns in $\mathrm{N}$ export and attenuation that change with farming practices and waterway connectivity are insidious obstacles to management $[33,34]$. $\mathrm{N}$ attenuation in small, agricultural waterways can be very dynamic, driven by fluctuations in prevailing catchment hydrology [33,35], as well as interactions with climate, vegetation, and soils [36]. Nutrient retention and processing may be higher at low discharges and warmer temperatures, while at high discharges, retention and processing can be negligible relative to the increased $\mathrm{N}$ flux from the land and upstream [33]. Along many agricultural waterways, fluxes of excess $\mathrm{N}$ 'lost' below the root zone are transported by subsurface drains or seepage channels [37-39], thus bypassing denitrification zones in shallow groundwater and riparian buffers $[37,40]$. Importantly, management interventions need to be effective over a range of $\mathrm{N}$ loading events [41] and across key $\mathrm{N}$ delivery flow pathways [16]. In temperate agricultural regions with waterlogged soils, peak $\mathrm{N}$ losses from subsurface drainage occur in the winter season after snowmelt, following heavy rainfall events, and when soil moisture conditions are saturated [33,42]. Furthermore, differences in hydrology and water chemistry from edge-of-field to in-stream nutrient sources also greatly influence $\mathrm{N}$ export and attenuation. Therefore, region-specific and site-specific knowledge of $\mathrm{N}$ export and attenuation are needed to inform optimal management outcomes at a range of scales.

Given the variable nature of the strength, times, and locations of $\mathrm{N}$ export from small agricultural catchments, characterizing $\mathrm{N}$ stocks and transport pathways in these systems can be perplexing. In particular, mapping the subsurface hydrologic pathways that transport $\mathrm{N}$ via shallow groundwater or subsurface drainage and quantifying their contributions to in-stream $\mathrm{N}$ present substantial challenges [43,44], but also opportunities for strategically targeting these with attenuation tools [45]. Similarly, delineating and targeting ephemerally or intermittently flowing swales, channels, and gullies that become hydrologically connected to waterway networks under specific hydrological conditions can be difficult, but these also present key intervention points for intercepting nutrients along critical transport pathways [46,47]. In recent years, mapping and modeling tools have improved to account for the temporal and spatial variability in waterway nutrient export and reveal how the connectivity of preferential flow pathways and transport pathways change across agricultural catchments $[12,13,48]$. Accounting for the contributions of small waterways to downstream $\mathrm{N}$ export provides a fundamental basis for improving $N$ management $[20,23]$, and therefore, our tool stacking framework targets attenuation tools to intercept $\mathrm{N}$ before it reaches larger, downstream waterways where it is more difficult and expensive to deal with.

Understanding the connectivity of $\mathrm{N}$ transport pathways and the variable hydrological and biogeochemical dynamics of $\mathrm{N}$ export in agricultural catchments and targeting these with scale-appropriate $\mathrm{N}$ attenuation tools using a 'systems thinking' approach pose a substantial management challenge [14,49]. A particular issue in designing approaches arises from the temporal inequality of $\mathrm{N}$ export caused by disproportionately high export during storm events, peak seasonal baseflows, or 'flashy' inputs along the waterway network [33,50,51]. In the case of groundwater nitrate pollution legacies seeping into streams [37,39], seasonally fluctuating shallow groundwater levels can be difficult to capture with attenuation tools [52-54]. Moreover, changes in the hydrology, water chemistry, and temperature of these inputs can together influence the microbially mediated processing rates and therefore the performance of attenuation tools $[52,55,56]$. For example, the efficacy of $\mathrm{N}$ management tools is limited by cooler water temperatures or high runoff volumes from snowmelt, particularly in cold climates [36]. The attenuation performance of a single tool can have different impacts in the receiving environment (i.e., changes in concentration or load), depending on what 
proportion of $\mathrm{N}$ is attenuated, and whether this primarily reduces mean $\mathrm{N}$ load or critical peaks in $\mathrm{N}$ concentration or $\mathrm{N}$ flux [57]. However, since it is generally impractical to scale tools to treat peak loading events, managers face a trade-off in dealing with such temporal inequality: either target $\mathrm{N}$ removal during more commonly occurring low, baseflow conditions, or design for more infrequently occurring, peak seasonal or event-driven flows that may transport a large proportion of annual loads or cause elevated peaks in concentration $[51,58]$.

Part of the solution to this trade-off is considering whether the receiving environment is more sensitive to critical $\mathrm{N}$ concentration impacts, such as toxicity to aquatic organisms or enhancing the proliferation of primary producers [3], or to $\mathrm{N}$ loads, such as nutrient loading in many lakes or estuaries $[34,59]$. In flowing waters with low retention times, the ecological sensitivity and biological responses to excess nutrients are greatest when inputs co-occur with periods of peak biological demand (e.g., during low stream flows in temperate zones that coincide with warmer seasonal temperatures) and if the input controls the time-weighted concentration during these periods (e.g., baseflow conditions or long-duration, continuous inputs) [58]. In comparison, because standing waters have long retention times, nutrient inputs can accumulate and contribute to internal loading during periods of greatest eutrophication risk, irrespective of the timing, duration, or magnitude of excess nutrient inputs [58]. Hence, different attenuation tools may have different impacts throughout a catchment, depending on the type and magnitude of change in the downstream N flux [57] and based on the sensitivity and type of receiving environment.

Overall, we suggest the suitability of $\mathrm{N}$ attenuation tools be evaluated based on the attenuation outcome for the receiving environment, and the delivery pathway and timing of $\mathrm{N}$ export. The $\mathrm{N}$ attenuation tools that we considered are described in Table 1 and discussed in the following section. Table 1 also includes the key components of a tool stacking framework based on $\mathrm{N}$ delivery pathways, timing, and change in the receiving environment (i.e., effect of flux reduction on $\mathrm{N}$ concentration or $\mathrm{N}$ load) from the edge-of-field to in-stream. A visual representation of the framework to help guide decision making is presented in Figure 1, using a selection of these tools as examples. 
Table 1. Overview of $\mathrm{N}$ attenuation tools that can be stacked across multiple locations and scales for small agricultural waterways. Tools are grouped by their location from the edge-of-field to in-stream. Potential benefits (B) and disbenefits (D), and published field study examples are provided.

\begin{tabular}{|c|c|c|c|c|c|c|}
\hline Location & N Attenuation Tool & $\begin{array}{l}\text { Baseflow Versus } \\
\text { Stormflow } \\
\text { Attenuation }\end{array}$ & $\begin{array}{l}\text { Intercepted Hydraulic Flow } \\
\text { Pathway }\end{array}$ & $\begin{array}{l}\text { Effect in the Receiving } \\
\text { Environment }\end{array}$ & Benefits and Disbenefits & Example \\
\hline \multirow{5}{*}{ 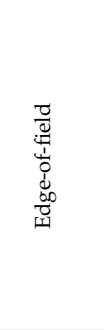 } & Exclude livestock & baseflow, stormflow & $\begin{array}{l}\text { surface drains/streams, } \\
\text { standing water, surface runoff }\end{array}$ & decreased load & $\begin{array}{l}\text { B: reduced stock losses, aesthetics } \\
\text { D: fence maintenance, alternative drinking water sources, and potential weed } \\
\text { management issues }\end{array}$ & [60-62] \\
\hline & $\begin{array}{l}\text { Redirect subsurface drainage (e.g., } \\
\text { controlled drainage) }\end{array}$ & baseflow, stormflow & tile drains & $\begin{array}{l}\text { decreased load, decreased } \\
\text { concentration peaks }\end{array}$ & $\begin{array}{l}\text { B: soil water storage, flood attenuation } \\
\text { D: requires active management }\end{array}$ & [63-66] \\
\hline & $\begin{array}{l}\text { Detain water (e.g., retention/detention } \\
\text { bunds, ponds, or basins) }\end{array}$ & stormflow & $\begin{array}{c}\text { standing surface water, surface } \\
\text { runoff }\end{array}$ & $\begin{array}{l}\text { decreased load, decreased } \\
\text { concentration peaks }\end{array}$ & $\begin{array}{l}\text { B: soil water storage, flood attenuation, can reduce drain clearance costs } \\
\text { D: requires active management }\end{array}$ & [67-70] \\
\hline & Retain grass filter strips and swales & stormflow & surface runoff, surface drains & $\begin{array}{l}\text { decreased load, decreased } \\
\text { concentration peaks }\end{array}$ & D: potential weed management issues & [71-73] \\
\hline & Install denitrification beds or walls & baseflow & tile drains, subsurface flow & decreased load & $\begin{array}{l}\text { B: little reduction of productive land } \\
\text { D: initial flush of organic carbon, anoxic effluent, dissolved phosphorus } \\
\text { release under anoxia, greenhouse gas production }\end{array}$ & {$[74-77]$} \\
\hline \multirow{3}{*}{ 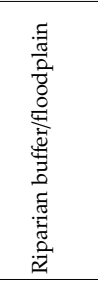 } & Construct or enhance wetlands & baseflow, stormflow & $\begin{array}{l}\text { floods, surface drains, tile } \\
\text { drains, standing surface water, } \\
\text { subsurface flow }\end{array}$ & $\begin{array}{l}\text { decreased load, decreased } \\
\text { concentration peaks }\end{array}$ & $\begin{array}{l}\text { B: able to cope with fluctuating water levels, stock water supply, waterfowl } \\
\text { habitat, flood attenuation, recreation, biodiversity value, landscape aesthetics } \\
\text { D: source of avian E.coli, dissolved phosphorus release under anoxia, } \\
\text { greenhouse gas production, nutrient impacts on natural wetland ecology }\end{array}$ & [78-81] \\
\hline & $\begin{array}{l}\text { Disconnect tile drains to saturate } \\
\text { riparian buffer }\end{array}$ & baseflow & tile drains & decreased load & $\begin{array}{l}\text { B: soil water storage, flood attenuation } \\
\text { D: requires active management }\end{array}$ & [40,82-84] \\
\hline & Plant riparian vegetation & baseflow & surface flow, subsurface flow & $\begin{array}{l}\text { decreased load, decreased } \\
\text { concentration peaks }\end{array}$ & $\begin{array}{l}\text { B: channel shading, improved aquatic habitat, wood and leaf supply to stream, } \\
\text { recreation, harvesting of biomass, biodiversity value, landscape aesthetics } \\
\text { D: requires some active vegetation management, shading might suppress } \\
\text { in-stream nutrient uptake }\end{array}$ & [85-87] \\
\hline \multirow{5}{*}{ 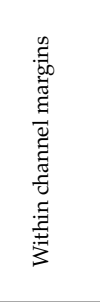 } & Reshape stream banks & baseflow, stormflow & $\begin{array}{l}\text { subsurface flow, surface } \\
\text { drains/streams, floods }\end{array}$ & $\begin{array}{l}\text { decreased load, decreased } \\
\text { concentration peaks }\end{array}$ & B: able to cope with fluctuating water levels & {$[24,88,89]$} \\
\hline & Create meander bends & baseflow & surface drains/streams & $\begin{array}{l}\text { decreased load, decreased } \\
\text { concentration peaks }\end{array}$ & $\begin{array}{l}\text { B: able to cope with fluctuating water levels, flood attenuation, biodiversity } \\
\text { value, landscape aesthetics }\end{array}$ & {$[24,90,91]$} \\
\hline & $\begin{array}{l}\text { Create inset floodplains } \\
\text { (e.g., two-stage channels) }\end{array}$ & baseflow, stormflow & $\begin{array}{l}\text { surface drains/streams, tile } \\
\text { drains, floods }\end{array}$ & $\begin{array}{l}\text { decreased load, decreased } \\
\text { concentration peaks }\end{array}$ & $\begin{array}{l}\text { B: able to cope with fluctuating water levels, flood attenuation, biodiversity } \\
\text { value }\end{array}$ & [92-95] \\
\hline & Widen channel & baseflow, stormflow & surface drains/streams, floods & decreased load & $\begin{array}{l}\text { B: able to cope with fluctuating water levels, flood attenuation } \\
\text { D: potential sedimentation issues, weed management }\end{array}$ & {$[24,96,97]$} \\
\hline & $\begin{array}{l}\text { Vegetate channel or maintain in-ditch } \\
\text { vegetation }\end{array}$ & baseflow & surface drains/streams & $\begin{array}{l}\text { decreased load, decreased } \\
\text { concentration peaks }\end{array}$ & $\begin{array}{l}\text { B: forage crop for stock, biodiversity value } \\
\begin{array}{l}\text { D: potential heightened flood risk, sedimentation issues, requires active } \\
\text { management }\end{array}\end{array}$ & [98-100] \\
\hline \multirow{5}{*}{ 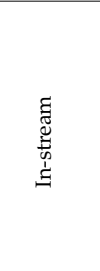 } & $\begin{array}{l}\text { Add in-stream geomorphic features } \\
\text { (e.g., boulders, riffles) }\end{array}$ & baseflow & surface drains/streams & decreased load & $\begin{array}{l}\text { B: biodiversity value, landscape aesthetics } \\
\text { D: heightened winter flood risk }\end{array}$ & {$[24,101,102]$} \\
\hline & $\begin{array}{l}\text { Add debris dams / } \\
\text { low-grade weirs }\end{array}$ & baseflow, stormflow & surface drains/streams, floods & $\begin{array}{l}\text { decreased load, decreased } \\
\text { concentration peaks }\end{array}$ & $\begin{array}{l}\text { B: able to cope with fluctuating water levels } \\
\text { D: heightened winter flood risk }\end{array}$ & {$[30,103,104]$} \\
\hline & Add large woody debris & baseflow & surface drains/streams & decreased load & $\begin{array}{l}\text { B: biodiversity value, landscape aesthetics } \\
\text { D: heightened winter flood risk }\end{array}$ & {$[24,29,105]$} \\
\hline & $\begin{array}{l}\text { Add organic matter } \\
\text { (e.g., leaves, small wood) }\end{array}$ & baseflow & surface drains/streams & decreased load & $\begin{array}{l}\text { B: biodiversity value } \\
\text { D: heightened winter flood risk }\end{array}$ & [106-109] \\
\hline & Add in-stream bioreactors & baseflow & surface drains/streams & decreased load & $\begin{array}{l}\text { D: initial flush of organic carbon, anoxic effluent, dissolved phosphorus } \\
\text { release under anoxia, greenhouse gas production }\end{array}$ & [110-113] \\
\hline
\end{tabular}



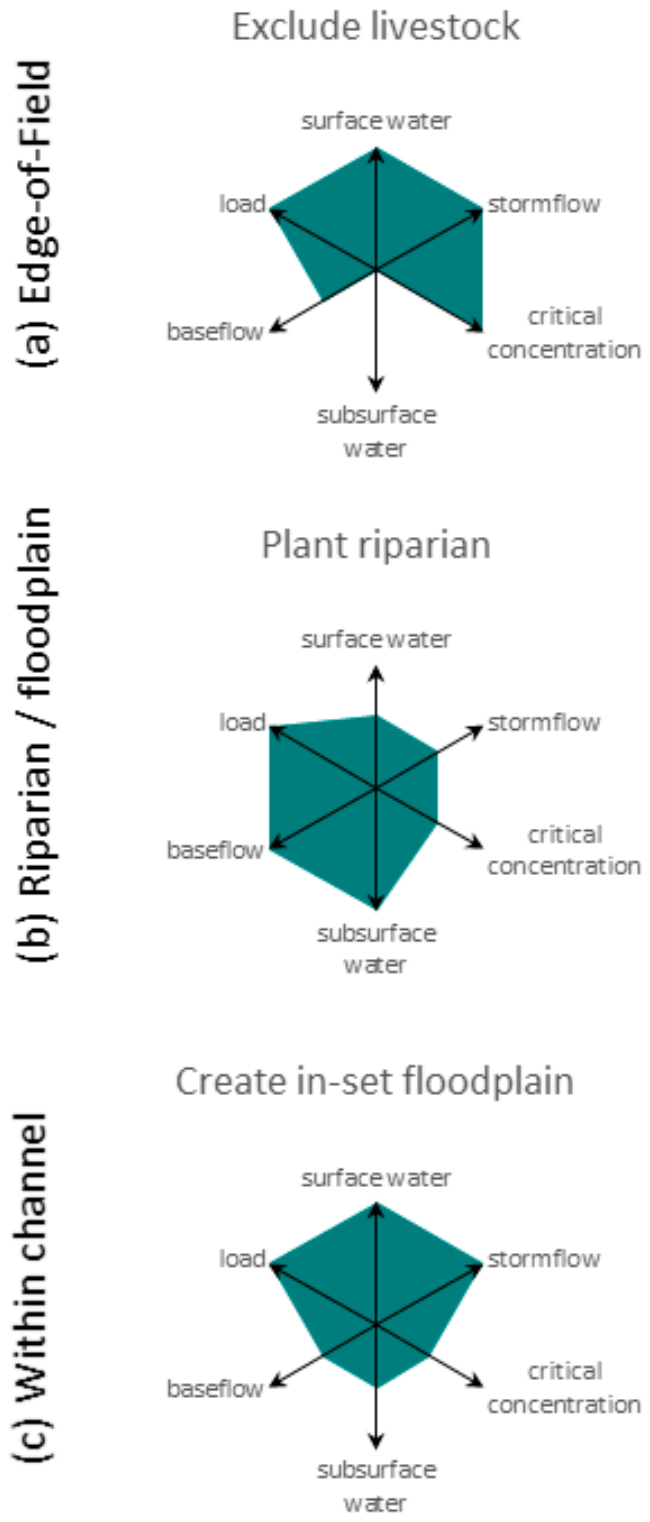

\section{Add low-head weir}

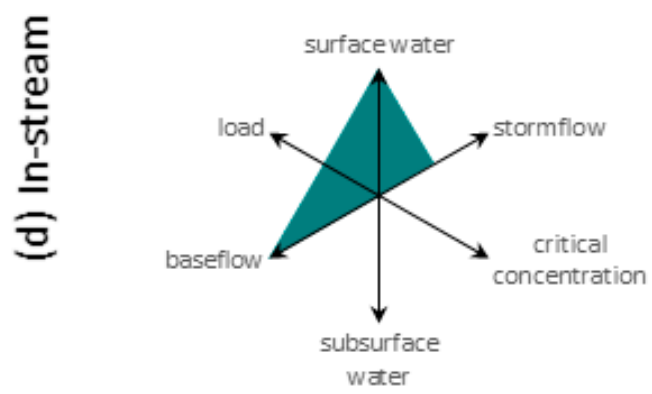

Controlled drainage

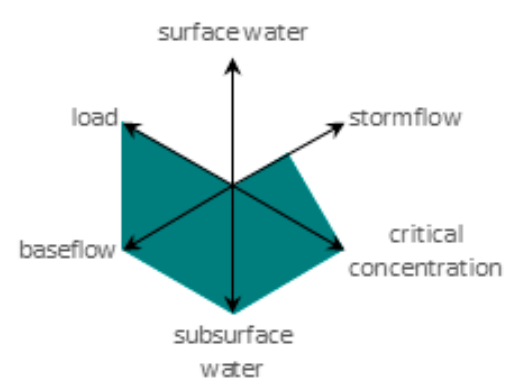

Construct wetland

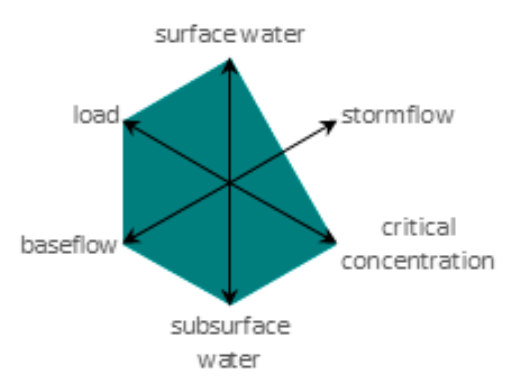

Vegetate channel

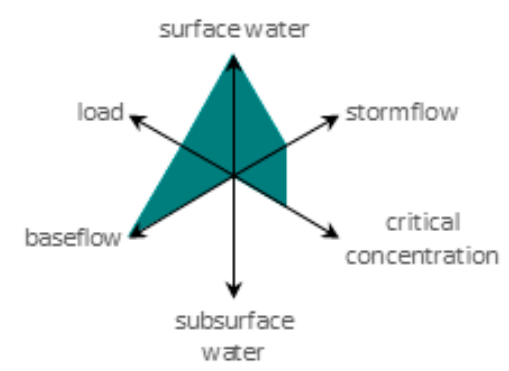

Add in-stream bioreactor

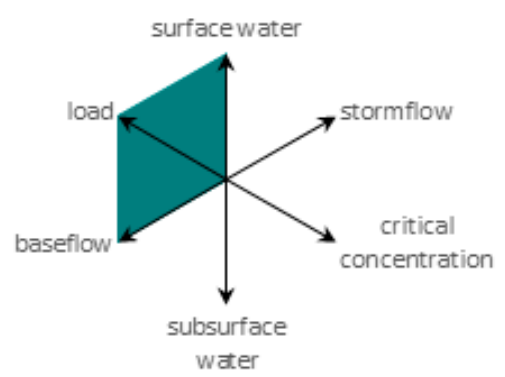

Figure 1. Potential suitability of $\mathrm{N}$ attenuation tool combinations across critical locations ordered from (a) the edge-of-field, (b) the riparian zone or floodplain, (c) within the channel margins, and finally to (d) in-stream. The three-axis framework (delivery pathway, timing, and change in the receiving environment) of the toolbox provides a visualization of tool stacking. Shapes denote the relative strengths for tools to target the flow pathway (surface to subsurface), timing (stormflow versus baseflow), and the effect of flux reduction on $\mathrm{N}$ concentration or $\mathrm{N}$ load in the receiving environment. 


\section{Expanding the $\mathbf{N}$ Toolbox to Boost Effectiveness from the Field Edge to In-Stream}

We present a collection of tools that can be implemented to intercept $\mathrm{N}$ from key transport pathways and enhance attenuation at multiple locations along small, agricultural waterways, targeting a range of $\mathrm{N}$ export scenarios (Table 1). A 'toolbox' approach should address the prevailing drivers of $\mathrm{N}$ loss in a complementary fashion along waterways (Figure 1). Here, 'toolbox' refers to a suite of options that are evidence-based and can be implemented to fit the local hydrological, social, and farming contexts [12]. Given the complementarity in the hydrological-targeting and $\mathrm{N}$ flux attenuation (Figure 1), our framework extends current knowledge to stack tools from the edge-of-field, in riparian buffers and floodplains, within the channel margins, to in-stream [24,104,114]. Stacking different tools across these locations helps to more fully address $\mathrm{N}$ attenuation by not only accommodating the hydrologic flow pathways and timing, but also by enhancing $\mathrm{N}$ removal and retention through multiple mechanisms [115]. $\mathrm{N}$ attenuation mechanisms that may be boosted include physical retention, microbially mediated transformation to gases, and biological retention from assimilation, uptake, or immobilization. Tool stacking $[16,18,19]$ should support functioning of multiple $\mathrm{N}$ attenuation mechanisms across locations and scales (Table 2). Moreover, implementing in-field, edge-of-field, and in-stream attenuation tools in a targeted and stacked way, focusing on small stream networks, may also provide the most cost-effective reduction of nutrient export from agricultural land to large river networks $[12,116,117]$. Given these potential advantages, we recommend adopting a toolbox-based N management approach that stacks multiple, different tools along and within the stream network to enhance the benefits provided by individual tools.

Table 2. Examples of how $\mathrm{N}$ attenuation tools can enhance multiple physical and biogeochemical attenuation processes. Tools are grouped by their location from the edge-of-field to in-stream. The attenuation mechanisms and criteria supported by tools were adopted from $[24,115,118]$. The degree to which tools boost these criteria is indicated as follows: + conditional/sometimes, ++ always, +++ exceptionally.

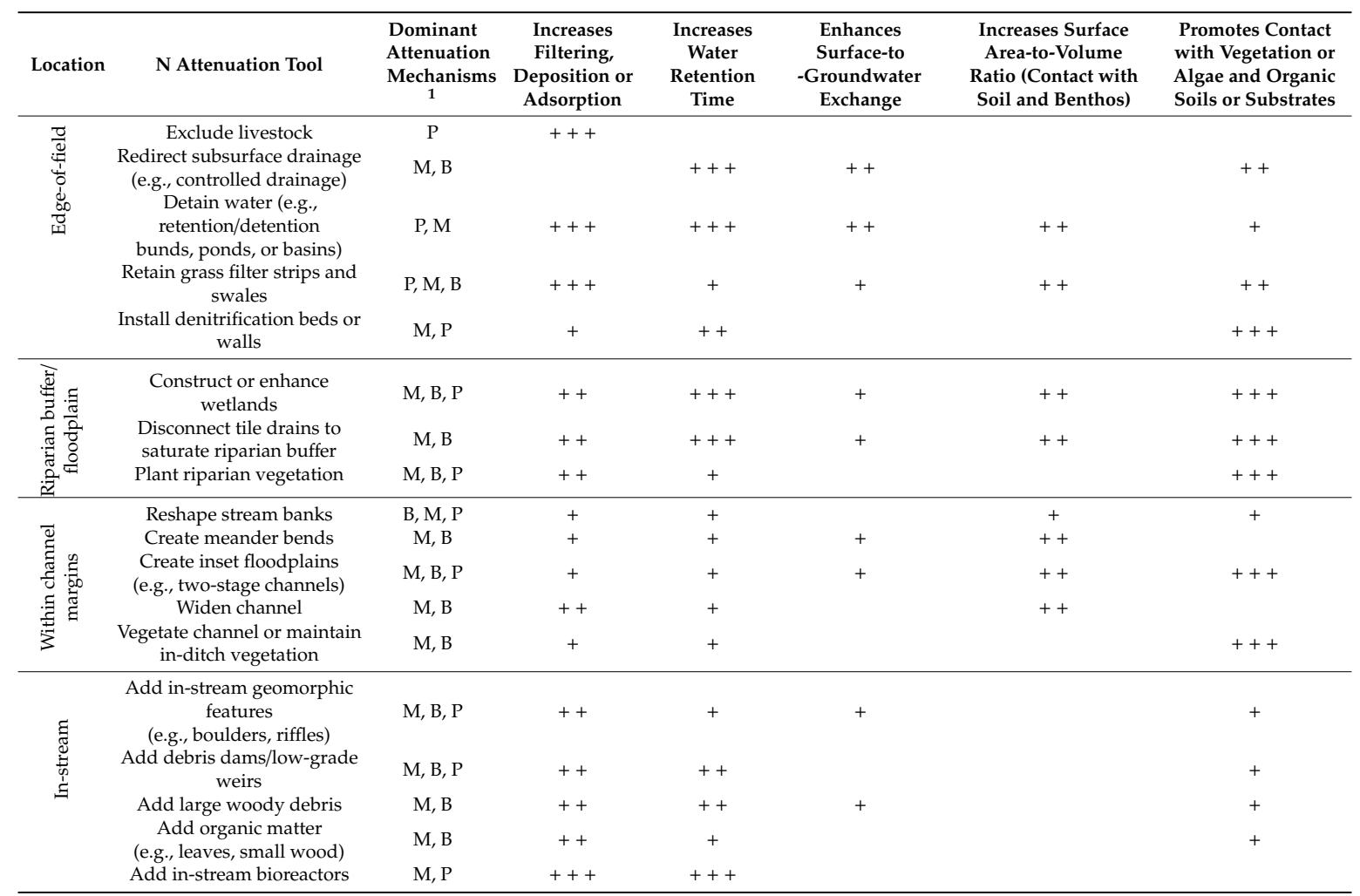

${ }^{1} \mathrm{P}=$ physical retention, $\mathrm{M}=$ microbially mediated transformation to gases, and $\mathrm{B}=$ biological retention from assimilation, uptake, or immobilization. 
Combining multiple attenuation tools across the key locations along the waterway network challenges the common, one-size-fits-all approach, which has often failed to improve water quality in receiving environments $[119,120]$. A growing body of evidence underscores the importance of managing riparian buffers and in-stream nutrient cycling to enhance attenuation through multiple pathways across a range of waterway hydrology and $\mathrm{N}$ export $[17,114]$. For example, filtering fine sediment and nutrients from surface run-off and subsurface flows in the riparian zone can enhance in-stream and hyporheic nutrient retention and removal [17,121]. Additionally, riparian vegetation can provide a source of organic matter to boost in-stream denitrification [108], as well as shading to regulate in-stream temperature and nuisance plant biomass [122,123], thereby mitigating in-stream eutrophication and responses to it [124,125]. Although riparian buffer $\mathrm{N}$ management approaches have become increasingly sophisticated to address multiple contaminants and provide ecological benefits to waterways [86], enhancing riparian vegetation alone may not be enough to attenuate catchment $\mathrm{N}$ in situations with legacy $\mathrm{N}$ from groundwater $[39,126]$ or stream sediments [91], or where subsurface tile drains or seepage zones bypass riparian buffers [37,127]. Thus, to address these challenges, contemporary riparian buffer management aims to restore structural components and functions associated with saturated soils and multiple vegetation types, and enhance processing with 'treatment train' components like bunds, wetlands, and intercepting subsurface drainage [86,128]. In contrast, combinations of multiple in-stream $\mathrm{N}$ attenuation tools such as two-stage channels, low-grade weirs, or in-stream bioreactors are far less common [104]. This is perhaps due to the comparatively low evidence base and uptake of in-stream tools as compared to edge-of-field or riparian tools [121], or because in-stream tools without riparian- and land-based $\mathrm{N}$ management are scarcely effective [17]. Although several experimental studies have demonstrated how stream management interventions at different locations along small agricultural waterway networks can attenuate excess N downstream [50,53,108], further field studies are required to assess the effectiveness and potential trade-offs between the abundance and spatial locations of stacking multiple, different tools to improve water quality and aquatic ecosystem health $[50,129]$. In light of these knowledge gaps and research needs, it seems advantageous that $\mathrm{N}$ attenuation toolboxes and tool stacking be conducted collaboratively with a range of scientific experts from different disciplines, practitioners, and farming communities to identify the appropriate tools and best tool combinations for local contexts.

\section{Moving Forward: Codeveloping and Implementing N Attenuation Toolboxes on Working Farms}

Real-world solutions for decreasing catchment $\mathrm{N}$ export must fit into working farms and landscapes; therefore, the people and the place (i.e., the local social and cultural context) should also influence waterway management [130]. We encourage scientists and practitioners to engage with farmers and the farm system early in the design process, because the implementation of $\mathrm{N}$ attenuation tools may interfere with agricultural production, drainage provision, and drain maintenance (Table 1). Importantly, procuring environmental benefits by implementing structural $\mathrm{N}$ attenuation tools often competes with the productive value of agricultural land [131]. Therefore, when implementing attenuation tools from a toolbox, tool suitability must be considered, based on space or land requirements, cost-effectiveness, social acceptability, and the anticipated physicochemical, hydromorphological, and ecological outcomes [132-134]. Hence, striving to provide optimal environmental improvements to small waterways in agricultural and other productive landscapes may require compromises from landowners. Given the local context for fitting the hydrological and social landscapes and the need to balance the potential benefits and disbenefits from attenuation tools (Table 1), we stress that it will be increasingly important for scientists and managers to codevelop attenuation toolboxes. They need to be implemented collaboratively with farmers to maximize environmental and on-farm benefits, as well as minimize potentially undesirable outcomes. Moreover, landowner engagement can enrich the science and practice of waterway management, whereby farmers provide 
sources of local knowledge and help to build trust networks that can snowball conservation efforts within a catchment [12,131].

Codevelopment with local knowledge holders to coproduce $\mathrm{N}$ management solutions with scientists and practitioners will also help enhance tool uptake $[135,136]$, but this requires effective translation and communication of the science for end-users [137]. Also, scientists and practitioners should be receptive to the local knowledge and insights that farmers can provide [138]. For example, walking along farm waterways with landowners and discussing farm and waterway management issues may reveal shared opportunities to jointly improve these by implementing suites of tools that suit the local context. This could be done by varying fenced buffer widths to encompass slumps and rills in pastures, using additional riparian plantings to fill in gaps, or implementing wetlands, bunds, or bioreactors at problematic wet spots at the edge-of-field. Therefore, we encourage that dialogue among scientists, practitioners, and farmers around selecting tool stacking combinations that best suit the local context consider how these target the delivery pathway, timing, and change in flux in the receiving environment (Figure 1; Table 1), how these enhance multiple physical and biogeochemical attenuation processes (Table 2), and the potential benefits and disbenefits (Table 1). Suitable $\mathrm{N}$ attenuation approaches for spring-fed waterways with stable baseflow hydrology could include saturated riparian buffers, bioreactors, and surface flow constructed wetlands to intercept tile drainage, shallow springs, or a portion of the stream water, and low-grade weirs or meanders to increase in-stream water and organic matter retention. In regions where waterways have flashier or more surface runoff-dominated hydrology, functionally based stream rehabilitation may need to involve a suite of tools designed to collect and intercept surface runoff, such as water detention bunds and sedimentation ponds, or increase hydraulic residence time and contact with the benthos across the stream channel, for example, with in-set floodplains or low-head weirs. By combining multiple tools to target a range of $\mathrm{N}$ loading locations and hydrological variability that limit the ability of waterways to attenuate nutrients, small agricultural waterways impacted by multiple stressors can behave more like linear wetlands [139], potentially providing greater ecosystem benefits than channelized ditches primarily intended to drain water from the landscape. Overall, this underscores the importance for land and catchment managers to 'think outside the box' by developing, implementing, and evaluating additional attenuation tools and practices at multiple influential locations on farms and within catchments.

\section{Conclusions}

Effective solutions to reducing excessive $\mathrm{N}$ in agricultural waterways require using multiple combinations of $\mathrm{N}$ attenuation tools, targeted along waterways at scale. Our tool stacking framework can be adopted so that field- or farm-scale management actions can be connected to water quality and ecosystem health outcomes at catchment scales. However, strategic frameworks should not replace using local hydrological data, expert judgment, and farmer knowledge, which can provide invaluable insights to help target attenuation tool stacking to fit the locations, timing, and change in $\mathrm{N}$ flux in headwater drainage networks. Hence, overcoming the challenges of targeting, combining, and scaling up efforts to improve how these waterways can attenuate $\mathrm{N}$ will require concerted efforts from scientists, practitioners, and landowners. Further research in different landscape and climate contexts is needed to demonstrate attenuation 'tool matching', where different tools are implemented at key locations along and within the stream network to attenuate catchment $\mathrm{N}$. We caution that $\mathrm{N}$ attenuation toolboxes should be treated as adaptive management experiments rather than solutions to nutrient loading issues, while better data on the catchment- and ecosystem-level impacts of combined land- and stream-based $\mathrm{N}$ management actions is obtained. Using a data-driven adaptive management approach, edge-of-field, riparian, within-channel, and in-stream attenuation tools can then be combined and scaled up accordingly so that additional ecological health and on-farm impacts can be incorporated in their design and implementation. 
Author Contributions: Conceptualization: B.C.G., C.M.F., L.A.M., J.S.H., F.E.M., C.C.T., and A.R.M.; writing-original draft preparation: B.C.G., C.M.F., J.S.H., and A.R.M.; writing-review and editing: B.C.G., C.M.F., L.A.M., J.S.H., F.E.M., C.C.T., and A.R.M.; visualization: B.C.G. and L.A.M.; supervision: C.M.F., L.A.M., J.S.H., F.E.M., C.C.T., and A.R.M; funding acquisition, J.S.H., F.E.M., and A.R.M. All authors have read and agreed to the published version of the manuscript.

Funding: The foundation for this work was funded from the Mackenzie Charitable Foundation as part of the Canterbury Waterway Rehabilitation Experiment (CAREX). Brandon Goeller was supported through a University of Canterbury Doctoral Scholarship. Catherine Febria was partly supported by a grant from New Zealand's Biological Heritage Science Challenge Project 3.4: Reigniting healthy resilience. Subsequent funding support for this work and extension of it has been provided by NIWA as a Strategic Science Investment via a post-doctoral fellowship for Brandon Goeller and through the SMARTer Riparian \& Wetland Strategies Research Programme.

Acknowledgments: The authors thank colleagues from New Zealand's National Institute of Water and Atmospheric Research and colleagues in the Freshwater Ecology Research Group (FERG) at the University of Canterbury for the critical discussions and constructive feedback. Earlier concepts for this manuscript benefited from comments and discussion with Marc Stutter (The James Hutton Institute), Roger Young (Cawthron Institute), and anonymous peer-reviewers.

Conflicts of Interest: The authors declare no conflict of interest. The funders had no role in the design of the study, in the writing of the manuscript, or in the decision to publish this work.

\section{References}

1. Harris, G.P.; Heathwaite, A.L. Why is achieving good ecological outcomes in rivers so difficult? Freshw. Biol. 2012, 57, 91-107. [CrossRef]

2. Glibert, P.M. Eutrophication, harmful algae and biodiversity — challenging paradigms in a world of complex nutrient changes. Mar. Pollut. Bull. 2017, 124, 591-606. [CrossRef]

3. Camargo, J.A.; Alonso, Á. Ecological and toxicological effects of inorganic nitrogen pollution in aquatic ecosystems: a global assessment. Environ. Int. 2006, 32, 831-849. [CrossRef]

4. Graham, S.E.; O’Brien, J.M.; Burrell, T.K.; McIntosh, A.R. Aquatic macrophytes alter productivity-richness relationships in eutrophic stream food webs. Ecosphere 2015, 6, Article-89. [CrossRef]

5. Dodds, W.K.; Oakes, R.M. Headwater influences on downstream water quality. Environ. Manag. 2008, 41, 367-377. [CrossRef]

6. David, M.B.; Drinkwater, L.E.; McIsaac, G.F. Sources of nitrate yields in the Mississippi River Basin. J. Environ. Qual. 2010, 39, 1657-1667. [CrossRef] [PubMed]

7. Novotny, V. Diffuse pollution from agriculture - A worldwide outlook. Water Sci. Technol. 1999, 39, 1-13. [CrossRef]

8. Cameron, K.C.; Di, H.J.; Moir, J.L. Nitrogen losses from the soil/plant system: a review. Ann. Appl. Biol. 2013, 162, 145-173. [CrossRef]

9. Monaghan, R.M.; de Klein, C.A.M.; Muirhead, R.W. Prioritisation of farm scale remediation efforts for reducing losses of nutrients and faecal indicator organisms to waterways: a case study of New Zealand dairy farming. J. Environ. Manage. 2008, 87, 609-622. [CrossRef] [PubMed]

10. Conley, D.J.; Paerl, H.W.; Howarth, R.W.; Boesch, D.F.; Seitzinger, S.P.; Havens, K.E.; Lancelot, C.; Likens, G.E. Controlling eutrophication: nitrogen and phosphorus. Science 2009, 323, 1014-1015. [CrossRef] [PubMed]

11. Haas, M.B.; Guse, B.; Fohrer, N. Assessing the impacts of Best Management Practices on nitrate pollution in an agricultural dominated lowland catchment considering environmental protection versus economic development. J. Environ. Manage. 2017, 196, 347-364. [CrossRef] [PubMed]

12. McLellan, E.L.; Schilling, K.E.; Wolter, C.F.; Tomer, M.D.; Porter, S.A.; Magner, J.A.; Smith, D.R.; Prokopy, L.S. Right practice, right place: a conservation planning toolbox for meeting water quality goals in the Corn Belt. J. Soil Water Conserv. 2018, 73, 29A-34A. [CrossRef]

13. Gascuel-Odoux, C.; Massa, F.; Durand, P.; Merot, P.; Troccaz, O.; Baudry, J.; Thenail, C. Framework and tools for agricultural landscape assessment relating to water quality protection. Environ. Manage. 2009, 43, 921-935. [CrossRef] [PubMed]

14. Tomer, M.D.; Porter, S.A.; James, D.E.; Boomer, K.M.B.; Kostel, J.A.; McLellan, E. Combining precision conservation technologies into a flexible framework to facilitate agricultural watershed planning. J. Soil Water Conserv. 2013, 68, 113A-120A. [CrossRef] 
15. McLellan, E.; Robertson, D.; Schilling, K.; Tomer, M.; Kostel, J.; Smith, D.; King, K. Reducing nitrogen export from the Corn Belt to the Gulf of Mexico: agricultural strategies for remediating hypoxia. JAWRA J. Am. Water Resour. Assoc. 2015, 51, 263-289. [CrossRef]

16. Lien, E.; Magner, J. Engineered biosystem treatment trains: a review of agricultural nutrient sequestration. Invent. J. Res. Technol. Eng. Manag. 2017, 1, 1-8.

17. Ranalli, A.J.; Macalady, D.L. The importance of the riparian zone and in-stream processes in nitrate attenuation in undisturbed and agricultural watersheds - a review of the scientific literature. J. Hydrol. 2010, 389, 406-415. [CrossRef]

18. Dabney, S.M.; Moore, M.T.; Locke, M.A. Integrated management of in-field, edge-of-field, and after-field buffers. J. Am. Water Resour. Assoc. 2006, 42, 15-24. [CrossRef]

19. Magner, J. Tailored Watershed Assessment and Integrated Management (TWAIM): a systems thinking approach. Water 2011, 3, 590-603. [CrossRef]

20. McDowell, R.W.; Cox, N.; Snelder, T.H. Assessing the yield and load of contaminants with stream order: would policy requiring livestock to be fenced out of high-order streams decrease catchment contaminant loads? J. Environ. Qual. 2017, 46, 1038-1047. [CrossRef]

21. Hughes, F.M.R.; Colston, A.; Mountford, J.O. Restoring riparian ecosystems: The challenge of accommodating variability and designing restoration trajectories. Ecol. Soc. 2005, 10, 1-22. [CrossRef]

22. Bernhardt, E.S.; Blaszczak, J.R.; Ficken, C.D.; Fork, M.L.; Kaiser, K.E.; Seybold, E.C. Control points in ecosystems: moving beyond the hot spot hot moment concept. Ecosystems 2017, 20, 665-682. [CrossRef]

23. Abbott, B.W.; Gruau, G.; Zarnetske, J.P.; Moatar, F.; Barbe, L.; Thomas, Z.; Fovet, O.; Kolbe, T.; Gu, S.; Pierson-Wickmann, A.-C.; et al. Unexpected spatial stability of water chemistry in headwater stream networks. Ecol. Lett. 2017, 21, 296-308. [CrossRef] [PubMed]

24. Craig, L.S.; Palmer, M.A.; Richardson, D.C.; Filoso, S.; Bernhardt, E.S.; Bledsoe, B.P.; Doyle, M.W.; Groffman, P.M.; Hassett, B.A.; Kaushal, S.S.; et al. Stream restoration strategies for reducing river nitrogen loads. Front. Ecol. Environ. 2008, 6, 529-538. [CrossRef]

25. Peterson, B.J.; Wollheim, W.M.; Mulholland, P.J.; Webster, J.R.; Meyer, J.L.; Tank, J.L.; Martí, E.; Bowden, W.B.; Valett, H.M.; Hershey, A.E.; et al. Control of nitrogen export from watersheds by headwater streams. Science 2001, 292, 86-90. [CrossRef] [PubMed]

26. Royer, T.V.; Tank, J.L.; David, M.B. Transport and fate of nitrate in headwater agricultural streams in Illinois. J. Environ. Qual. 2004, 33, 1296-1304. [CrossRef]

27. Bernot, M.J.; Tank, J.L.; Royer, T.V.; David, M.B. Nutrient uptake in streams draining agricultural catchments of the midwestern United States. Freshw. Biol. 2006, 51, 499-509. [CrossRef]

28. Kröger, R.; Holland, M.M.; Moore, M.T.; Cooper, C.M. Hydrological variability and agricultural drainage ditch inorganic nitrogen reduction capacity. J. Environ. Qual. 2007, 36, 1646-1652. [CrossRef]

29. Ensign, S.H.; Doyle, M.W. In-channel transient storage and associated nutrient retention: Evidence from experimental manipulations. Limnol. Oceanogr. 2005, 50, 1740-1751. [CrossRef]

30. Kröger, R.; Moore, M.T.; Farris, J.L.; Gopalan, M. Evidence for the use of low-grade weirs in drainage ditches to improve nutrient reductions from agriculture. Water. Air. Soil Pollut. 2011, 221, 223-234. [CrossRef]

31. Alexander, R.B.; Boyer, E.W.; Smith, R.A.; Schwarz, G.E.; Moore, R.B. The role of headwater streams in downstream water quality. JAWRA J. Am. Water Resour. Assoc. 2007, 43, 41-59. [CrossRef] [PubMed]

32. Thomas, G. Improving restoration practice by deriving appropriate techniques from analysing the spatial organization of river networks. Limnol.-Ecol. Manag. Inland Waters 2014, 45, 50-60. [CrossRef]

33. Royer, T.V.; David, M.B.; Gentry, L.E. Timing of riverine export of nitrate and phosphorus from agricultural watersheds in Illinois: implications for reducing nutrient loading to the Mississippi River. Environ. Sci. Technol. 2006, 40, 4126-4131. [CrossRef] [PubMed]

34. Baker, J.L.; David, M.B.; Lemke, D.W.; Jaynes, D.B. Understanding nutrient fate and transport, including the importance of hydrology in determining field losses. In Final Report: Gulf Hypoxia and Local Water Quality Concerns Workshop; Upper Mississippi River Subbasin Hypoxia Nutrient Committee, Ed.; American Society of Agricultural and Biological Engineers: St. Joseph, Michigan, 2008; pp. 1-17.

35. Monaghan, R.M.; Smith, L.C.; Muirhead, R.W. Pathways of contaminant transfers to water from an artificially-drained soil under intensive grazing by dairy cows. Agric. Ecosyst. Environ. 2016, 220, 76-88. [CrossRef] 
36. Liu, J.; Baulch, H.M.; Macrae, M.L.; Wilson, H.F.; Elliott, J.A.; Bergström, L.; Glenn, A.J.; Vadas, P.A. Agricultural water quality in cold climates: processes, drivers, management options, and research needs. J. Environ. Qual. 2019, 48, 792. [CrossRef]

37. Williams, M.R.; Buda, A.R.; Elliott, H.A.; Singha, K.; Hamlett, J. Influence of riparian seepage zones on nitrate variability in two agricultural headwater streams. JAWRA J. Am. Water Resour. Assoc. 2015, 51, 883-897. [CrossRef]

38. Williams, M.R.; King, K.W.; Fausey, N.R. Contribution of tile drains to basin discharge and nitrogen export in a headwater agricultural watershed. Agric. Water Manag. 2015, 158, 42-50. [CrossRef]

39. Goeller, B.C.; Febria, C.M.; Warburton, H.J.; Hogsden, K.L.; Collins, K.E.; Devlin, H.S.; Harding, J.S.; McIntosh, A.R. Springs drive downstream nitrate export from artificially-drained agricultural headwater catchments. Sci. Total Environ. 2019, 671, 119-128. [CrossRef]

40. Jaynes, D.B.; Isenhart, T.M. Reconnecting tile drainage to riparian buffer hydrology for enhanced nitrate removal. J. Environ. Qual. 2014, 43, 631-638. [CrossRef]

41. Jordan, S.J.; Stoffer, J.; Nestlerode, J.A. Wetlands as sinks for reactive nitrogen at continental and global scales: a meta-analysis. Ecosystems 2011, 14, 144-155. [CrossRef]

42. Bauwe, A.; Tiemeyer, B.; Kahle, P.; Lennartz, B. Classifying hydrological events to quantify their impact on nitrate leaching across three spatial scales. J. Hydrol. 2015, 531, 589-601. [CrossRef]

43. Robinson, D.A.; Binley, A.; Crook, N.; Day-Lewis, F.D.; Ferré, T.P.A.; Grauch, V.J.S.; Knight, R.; Knoll, M.; Lakshmi, V.; Miller, R.; et al. Advancing process-based watershed hydrological research using near-surface geophysics: a vision for, and review of, electrical and magnetic geophysical methods. Hydrol. Process. 2008, 22, 3604-3635. [CrossRef]

44. Blume, T.; van Meerveld, H.J. From hillslope to stream: methods to investigate subsurface connectivity. Wiley Interdiscip. Rev. Water 2015, 2, 177-198. [CrossRef]

45. Rittenburg, R.A.; Squires, A.L.; Boll, J.; Brooks, E.S.; Easton, Z.M.; Steenhuis, T.S. Agricultural BMP effectiveness and dominant hydrological flow paths: concepts and a review. JAWRA J. Am. Water Resour. Assoc. 2015, 51, 305-329. [CrossRef]

46. McDonnell, J.J. Are all runoff processes the same? Hydrol. Process. 2013, 27, 4103-4111. [CrossRef]

47. Covino, T. Hydrologic connectivity as a framework for understanding biogeochemical flux through watersheds and along fluvial networks. Geomorphology 2017, 277, 133-144. [CrossRef]

48. Deakin, J.; Flynn, R.; Archbold, M.; Daly, D.; O’Brien, R.; Orr, A.; Misstear, N. Understanding pathways transferring nutrients to streams: review of a major Irish study and its implications for determining water quality management strategies. Biol. Environ. Proc. R. Ir. Acad. 2016, 116B, 233-243. [CrossRef]

49. Giri, S.; Nejadhashemi, A.P.; Woznicki, S.; Zhang, Z. Analysis of best management practice effectiveness and spatiotemporal variability based on different targeting strategies. Hydrol. Process. 2014, 28, 431-445. [CrossRef]

50. Pearce, N.J.T.; Yates, A.G. Intra-annual variation of the association between agricultural best management practices and stream nutrient concentrations. Sci. Total Environ. 2017, 586, 1124-1134. [CrossRef]

51. Williams, M.R.; King, K.W.; Penn, C.J. Integrating temporal inequality into conservation planning to improve practice design and efficacy. JAWRA J. Am. Water Resour. Assoc. 2018, 54, 1039-1054. [CrossRef]

52. Hill, A.R. Groundwater nitrate removal in riparian buffer zones: a review of research progress in the past 20 years. Biogeochemistry 2019, 143, 347-369. [CrossRef]

53. Goeller, B.C.; Burbery, L.F.; Febria, C.M.; Collins, K.E.; Burrows, N.J.; Simon, K.S.; Harding, J.S.; McIntosh, A.R. Capacity for bioreactors and riparian rehabilitation to enhance nitrate attenuation in agricultural streams. Ecol. Eng. 2019, 134, 65-77. [CrossRef]

54. Balestrini, R.; Sacchi, E.; Tidili, D.; Delconte, C.A.; Buffagni, A. Factors affecting agricultural nitrogen removal in riparian strips: Examples from groundwater-dependent ecosystems of the Po Valley (Northern Italy). Agric. Ecosyst. Environ. 2016, 221, 132-144. [CrossRef]

55. Tanner, C.C.; Kadlec, R.H. Influence of hydrological regime on wetland attenuation of diffuse agricultural nitrate losses. Ecol. Eng. 2013, 56, 79-88. [CrossRef]

56. Goeller, B.C.; Febria, C.M.; Harding, J.S.; McIntosh, A.R. Thinking beyond the bioreactor box: incorporating stream ecology into edge-of-field nitrate management. J. Environ. Qual. 2016, 45, 866-872. [CrossRef] [PubMed] 
57. Viaud, V.; Merot, P.; Baudry, J. Hydrochemical buffer assessment in agricultural landscapes: from local to catchment scale. Environ. Manage. 2004, 34, 559-573. [CrossRef]

58. Stamm, C.; Jarvie, H.P.; Scott, T. What's more important for managing phosphorus: loads, concentrations or both? Environ. Sci. Technol. 2014, 48, 23-24. [CrossRef]

59. Dodds, W.K.; Bouska, W.W.; Eitzmann, J.L.; Pilger, T.J.; Pitts, K.L.; Riley, A.J.; Schloesser, J.T.; Thornbrugh, D.J. Eutrophication of U.S. freshwaters: analysis of potential economic damages. Environ. Sci. Technol. 2009, 43, 12-19. [CrossRef]

60. Davies-Colley, R.J.; Nagels, J.W.; Smith, R.A.; Young, R.G.; Phillips, C.J. Water quality impact of a dairy cow herd crossing a stream. N. Z. J. Mar. Freshw. Res. 2004, 38, 569-576. [CrossRef]

61. Hughes, A.O.; Tanner, C.C.; McKergow, L.A.; Sukias, J.P.S. Unrestricted dairy cattle grazing of a pastoral headwater wetland and its effect on water quality. Agric. Water Manag. 2016, 165, 72-81. [CrossRef]

62. O'Callaghan, P.; Kelly-Quinn, M.; Jennings, E.; Antunes, P.; O’Sullivan, M.; Fenton, O.; hUallacháin, D.Ó. The environmental impact of cattle access to watercourses: a review. J. Environ. Qual. 2019, 48, 340-351. [CrossRef] [PubMed]

63. Jia, Z.; Evans, R.O.; Smith, J.T. Effect of controlled drainage and vegetative buffers on drainage water quality from wastewater irrigated fields. J. Irrig. Drain. Eng. 2006, 132, 159-170. [CrossRef]

64. Woli, K.P.; David, M.B.; Cooke, R.A.; McIsaac, G.F.; Mitchell, C.A. Nitrogen balance in and export from agricultural fields associated with controlled drainage systems and denitrifying bioreactors. Ecol. Eng. 2010, 36, 1558-1566. [CrossRef]

65. Bonaiti, G.; Borin, M. Efficiency of controlled drainage and subirrigation in reducing nitrogen losses from agricultural fields. Agric. Water Manag. 2010, 98, 343-352. [CrossRef]

66. Carstensen, M.V.; Børgesen, C.D.; Ovesen, N.B.; Poulsen, J.R.; Hvid, S.K.; Kronvang, B. Controlled drainage as a targeted mitigation measure for nitrogen and phosphorus. J. Environ. Qual. 2019, 48, 677-685. [CrossRef] [PubMed]

67. Edwards, C.L.; Shannon, R.D.; Jarrett, A.R. Sedimentation basin retention efficiencies for sediment, nitrogen, and phosphorus from simulated agricultural runoff. Trans. ASAE 1999, 403-409. [CrossRef]

68. Wang, X.H.; Yin, C.Q.; Shan, B.Q. The role of diversified landscape buffer structures for water quality improvement in an agricultural watershed, North China. Agric. Ecosyst. Environ. 2005, 107, 381-396. [CrossRef]

69. Fiener, P.; Auerswald, K.; Weigand, S. Managing erosion and water quality in agricultural watersheds by small detention ponds. Agric. Ecosyst. Environ. 2005, 110, 132-142. [CrossRef]

70. Chrétien, F.; Gagnon, P.; Thériault, G.; Guillou, M. Performance analysis of a wet-retention pond in a small agricultural catchment. J. Environ. Eng. 2016, 142, 04016005. [CrossRef]

71. Smith, C.M. Riparian pasture retirement effects on sediment, phosphorus, and nitrogen in channellised surface run-off from pastures. N. Z. J. Mar. Freshw. Res. 1989, 23, 139-146. [CrossRef]

72. Daniels, R.B.; Gilliam, J.W. Sediment and chemical load reduction by grass and riparian filters. Soil Sci. Soc. Am. J. 1996, 60, 246-251. [CrossRef]

73. Clausen, J.C.; Guillard, K.; Sigmund, C.M.; Dors, K.M. Water quality changes from riparian buffer restoration in Connecticut. J. Environ. Qual. 2000, 29, 1751-1761. [CrossRef]

74. Long, L.M.; Schipper, L.A.; Bruesewitz, D.A. Long-term nitrate removal in a denitrification wall. Agric. Ecosyst. Environ. 2011, 140, 514-520. [CrossRef]

75. Schmidt, C.A.; Clark, M.W. Evaluation of a denitrification wall to reduce surface water nitrogen loads. J. Environ. Qual. 2012, 41, 724-731. [CrossRef] [PubMed]

76. Moorman, T.B.; Tomer, M.D.; Smith, D.R.; Jaynes, D.B. Evaluating the potential role of denitrifying bioreactors in reducing watershed-scale nitrate loads: a case study comparing three Midwestern (USA) watersheds. Ecol. Eng. 2015, 75, 441-448. [CrossRef]

77. Addy, K.; Gold, A.J.; Christianson, L.E.; David, M.B.; Schipper, L.A.; Ratigan, N.A. Denitrifying bioreactors for nitrate removal: a meta-analysis. J. Environ. Qual. 2016, 45, 873-881. [CrossRef]

78. Kovacic, D.A.; David, M.B.; Gentry, L.E.; Starks, K.M.; Cooke, R.A. Effectiveness of constructed wetlands in reducing nitrogen and phosphorus export from agricultural tile drainage. J. Environ. Qual. 2000, 29, 1262-1274. [CrossRef]

79. Tanner, C.C.; Sukias, J.P.S.; Yates, C.R. New Zealand Guidelines: Constructed Wetland Treatment of tile Drainage; National Institute of Water \& Atmospheric Research Ltd.: Hamilton, New Zealand, 2010. 
80. Tanner, C.C.; Sukias, J.P.S. Multiyear nutrient removal performance of three constructed wetlands intercepting tile drain flows from grazed pastures. J. Environ. Qual. 2011, 40, 620-633. [CrossRef]

81. Hefting, M.M.; van den Heuvel, R.N.; Verhoeven, J.T.A. Wetlands in agricultural landscapes for nitrogen attenuation and biodiversity enhancement: opportunities and limitations. Ecol. Eng. 2013, 56, 5-13. [CrossRef]

82. Jaynes, D.B.; Isenhart, T.M. Performance of saturated riparian buffers in Iowa, USA. J. Environ. Qual. 2019, 48, 289-296. [CrossRef]

83. Tomer, M.D.; Jaynes, D.B.; Porter, S.A.; James, D.E.; Isenhart, T.M. Identifying riparian zones best suited to installation of saturated buffers: a preliminary multi-watershed assessment. In Precision Conservation: Geospatial Techniques for Agricultural and Natural Resources Conservation; Delgado, J., Sassenrath, G., Mueller, T., Eds.; Agronomy Monographs; ASA, CSSA, and SSSA: Madison, Wisconsin, USA, 2017.

84. Davis, M.P.; Groh, T.A.; Jaynes, D.B.; Parkin, T.B.; Isenhart, T.M. Nitrous oxide emissions from saturated riparian buffers: are we trading a water quality problem for an air quality problem? J. Environ. Qual. 2018, 48, 261-269. [CrossRef] [PubMed]

85. Fennessy, M.S.; Cronk, J.K. The effectiveness and restoration potential of riparian ecotones for the management of nonpoint source pollution, particularly nitrate. Crit. Rev. Environ. Sci. Technol. 1997,27, 285-317. [CrossRef]

86. Stutter, M.; Kronvang, B.; Ó hUallacháin, D.; Rozemeijer, J. Current insights into the effectiveness of riparian management, attainment of multiple benefits, and potential technical enhancements. J. Environ. Qual. 2019, 48, 236-247. [CrossRef] [PubMed]

87. Valkama, E.; Usva, K.; Saarinen, M.; Uusi-Kämppä, J. A meta-analysis on nitrogen retention by buffer zones. J. Environ. Qual. 2019, 48, 270-279. [CrossRef]

88. Welsh, M.K.; McMillan, S.K.; Vidon, P.G. Denitrification along the stream-riparian continuum in restored and unrestored agricultural streams. J. Environ. Qual. 2017, 46, 1010-1019. [CrossRef]

89. Webster, A.J.; Groffman, P.M.; Cadenasso, M.L. Controls on denitrification potential in nitrate-rich waterways and riparian zones of an irrigated agricultural setting. Ecol. Appl. 2018, 28, 1055-1067. [CrossRef]

90. Kasahara, T.; Hill, A.R. Lateral hyporheic zone chemistry in an artificially constructed gravel bar and a re-meandered stream channel, Southern Ontario, Canada. JAWRA J. Am. Water Resour. Assoc. 2007, 43, 1257-1269. [CrossRef]

91. Weigelhofer, G.; Welti, N.; Hein, T. Limitations of stream restoration for nitrogen retention in agricultural headwater streams. Ecol. Eng. 2013, 60, 224-234.

92. Roley, S.S.; Tank, J.L.; Stephen, M.L.; Johnson, L.T.; Beaulieu, J.J.; Witter, J.D. Floodplain restoration enhances denitrification and reach-scale nitrogen removal in an agricultural stream. Ecol. Appl. 2012, 22, 281-297. [CrossRef]

93. Mahl, U.H.; Tank, J.L.; Roley, S.S.; Davis, R.T. Two-stage ditch floodplains enhance N-removal capacity and reduce turbidity and dissolved $\mathrm{P}$ in agricultural streams. JAWRA J. Am. Water Resour. Assoc. 2015, 51, 923-940. [CrossRef]

94. Hodaj, A.; Bowling, L.C.; Frankenberger, J.R.; Chaubey, I. Impact of a two-stage ditch on channel water quality. Agric. Water Manag. 2017, 192, 126-137. [CrossRef]

95. Hanrahan, B.R.; Tank, J.L.; Dee, M.M.; Trentman, M.T.; Berg, E.M.; McMillan, S.K. Restored floodplains enhance denitrification compared to naturalized floodplains in agricultural streams. Biogeochemistry 2018, 1-19. [CrossRef]

96. Riley, W.D.; Potter, E.C.E.; Biggs, J.; Collins, A.L.; Jarvie, H.P.; Jones, J.I.; Kelly-Quinn, M.; Ormerod, S.J.; Sear, D.A.; Wilby, R.L.; et al. Small water bodies in Great Britain and Ireland: ecosystem function, human-generated degradation, and options for restorative action. Sci. Total Environ. 2018, 645, 1598-1616. [CrossRef] [PubMed]

97. Booman, G.C.; Laterra, P. Channelizing streams for agricultural drainage impairs their nutrient removal capacity. J. Environ. Qual. 2019, 48, 459-469. [CrossRef] [PubMed]

98. Soana, E.; Bartoli, M.; Milardi, M.; Fano, E.A.; Castaldelli, G. An ounce of prevention is worth a pound of cure: managing macrophytes for nitrate mitigation in irrigated agricultural watersheds. Sci. Total Environ. 2019, 647, 301-312. [CrossRef] [PubMed]

99. Castaldelli, G.; Soana, E.; Racchetti, E.; Vincenzi, F.; Fano, E.A.; Bartoli, M. Vegetated canals mitigate nitrogen surplus in agricultural watersheds. Agric. Ecosyst. Environ. 2015, 212, 253-262. [CrossRef] 
100. Soana, E.; Balestrini, R.; Vincenzi, F.; Bartoli, M.; Castaldelli, G. Mitigation of nitrogen pollution in vegetated ditches fed by nitrate-rich spring waters. Agric. Ecosyst. Environ. 2017, 243, 74-82. [CrossRef]

101. Kasahara, T.; Hill, A.R. Effects of riffle step restoration on hyporheic zone chemistry in N-rich lowland streams. Can. J. Fish. Aquat. Sci. 2006, 63, 120-133. [CrossRef]

102. Lautz, L.K.; Fanelli, R.M. Seasonal biogeochemical hotspots in the streambed around restoration structures. Biogeochemistry 2008, 91, 85-104. [CrossRef]

103. Kröger, R.; Scott, J.T.; Czarnecki, J.M.P. Denitrification potential of low-grade weirs and agricultural drainage ditch sediments in the Lower Mississippi Alluvial Valley. Ecol. Eng. 2014, 73, 168-175. [CrossRef]

104. Faust, D.R.; Kröger, R.; Moore, M.T.; Rush, S.A. Management practices used in agricultural drainage ditches to reduce Gulf of Mexico hypoxia. Bull. Environ. Contam. Toxicol. 2017, 100, 32-40. [CrossRef]

105. Lazar, J.G.; Gold, A.J.; Addy, K.; Mayer, P.M.; Forshay, K.J.; Groffman, P.M. Instream large wood: denitrification hotspots with low $\mathrm{N}_{2} \mathrm{O}$ production. JAWRA J. Am. Water Resour. Assoc. 2014, 50, 615-625. [CrossRef]

106. Shipitalo, M.J.; Bonta, J.V.; Dayton, E.A.; Owens, L.B. Impact of grassed waterways and compost filter socks on the quality of surface runoff from corn fields. J. Environ. Qual. 2010, 39, 1009-1018. [CrossRef] [PubMed]

107. Faust, D.R.; Kröger, R.; Miranda, L.E.; Rush, S.A. Nitrate removal from agricultural drainage ditch sediments with amendments of organic carbon: potential for an innovative best management practice. Water. Air. Soil Pollut. 2016, 10, 378-387. [CrossRef]

108. O’Brien, J.M.; Warburton, H.J.; Graham, S.E.; Franklin, H.M.; Febria, C.M.; Hogsden, K.L.; Harding, J.S.; McIntosh, A.R. Leaf litter additions enhance stream metabolism, denitrification, and restoration prospects for agricultural catchments. Ecosphere 2017, 8, e02018. [CrossRef]

109. Nifong, R.L.; Taylor, J.M.; Moore, M.T. Mulch-derived organic carbon stimulates high denitrification fluxes from agricultural ditch sediments. J. Environ. Qual. 2019, 48, 476-484. [CrossRef]

110. Robertson, W.D.; Merkley, L.C. In-stream bioreactor for agricultural nitrate treatment. J. Environ. Qual. 2009, 38, 230-237. [CrossRef]

111. Elgood, Z.; Robertson, W.D.; Schiff, S.L.; Elgood, R. Nitrate removal and greenhouse gas production in a stream-bed denitrifying bioreactor. Ecol. Eng. 2010, 36, 1575-1580. [CrossRef]

112. Pfannerstill, M.; Kühling, I.; Hugenschmidt, C.; Trepel, M.; Fohrer, N. Reactive ditches: A simple approach to implement denitrifying wood chip bioreactors to reduce nitrate exports into aquatic ecosystems? Environ. Earth Sci. 2016, 75, 1063-1073. [CrossRef]

113. Sarris, T.S.; Burbery, L.F. Stochastic multi-objective performance optimization of an in-stream woodchip denitrifying bioreactor. Ecol. Eng. 2018, 124, 38-50. [CrossRef]

114. Newcomer Johnson, T.; Kaushal, S.; Mayer, P.; Smith, R.; Sivirichi, G. Nutrient retention in restored streams and rivers: a global review and synthesis. Water 2016, 8, 116. [CrossRef]

115. Burgin, A.J.; Hamilton, S.K. Have we overemphasized the role of denitrification in aquatic ecosystems? a review of nitrate removal pathways. Front. Ecol. Environ. 2007, 5, 89-96. [CrossRef]

116. Schoumans, O.F.; Chardon, W.J.; Bechmann, M.E.; Gascuel-Odoux, C.; Hofman, G.; Kronvang, B.; Rubæk, G.H.; Ulén, B.; Dorioz, J.-M. Mitigation options to reduce phosphorus losses from the agricultural sector and improve surface water quality: A review. Sci. Total Environ. 2014, 468-469, 1255-1266. [CrossRef] [PubMed]

117. Roley, S.S.; Tank, J.L.; Tyndall, J.C.; Witter, J.D. How cost-effective are cover crops, wetlands, and two-stage ditches for nitrogen removal in the Mississippi River Basin? Water Resour. Econ. 2016, 15, 43-56. [CrossRef]

118. Seitzinger, S.; Harrison, J.A.; Böhlke, J.K.; Bouwman, A.F.; Lowrance, R.; Peterson, B.; Tobias, C.; Drecht, G.V. Denitrification across landscapes and waterscapes: a synthesis. Ecol. Appl. 2006, 16, 2064-2090. [CrossRef]

119. Filoso, S.; Palmer, M.A. Assessing stream restoration effectiveness at reducing nitrogen export to downstream waters. Ecol. Appl. 2011, 21, 1989-2006. [CrossRef]

120. Doyle, M.W.; Shields, F.D. Compensatory mitigation for streams under the Clean Water Act: reassessing science and redirecting policy. JAWRA J. Am. Water Resour. Assoc. 2012, 48, 494-509. [CrossRef]

121. Lammers, R.W.; Bledsoe, B.P. What role does stream restoration play in nutrient management? Crit. Rev. Environ. Sci. Technol. 2017, 47, 335-371. [CrossRef]

122. Collier, K.J.; Cooper, A.B.; Davies-Colley, R.J.; Rutherford, J.C.; Smith, C.M.; Williamson, R.B. Managing Riparian Zones: A Contribution to Protecting New Zealand's Rivers and Streams; Department of Conservation: Wellington, New Zealand, 1995.

123. Ellawala Kankanamge, C.; Matheson, F.E.; Riis, T. Shading constrains the growth of invasive submerged macrophytes in streams. Aquat. Bot. 2019, 158, 1-7. [CrossRef] 
124. Burrell, T.K.; O’Brien, J.M.; Graham, S.E.; Simon, K.S.; Harding, J.S.; McIntosh, A.R. Riparian shading mitigates stream eutrophication in agricultural catchments. Freshw. Sci. 2014, 33, 73-84. [CrossRef]

125. Halliday, S.J.; Skeffington, R.A.; Wade, A.J.; Bowes, M.J.; Read, D.S.; Jarvie, H.P.; Loewenthal, M. Riparian shading controls instream spring phytoplankton and benthic algal growth. Env. Sci Process. Impacts 2016, 18, 677-689. [CrossRef] [PubMed]

126. Meals, D.W.; Dressing, S.A.; Davenport, T.E. Lag time in water quality response to best management practices: a review. J. Environ. Qual. 2010, 39, 85-96. [CrossRef] [PubMed]

127. Weller, D.E.; Baker, M.E. Cropland riparian buffers throughout Chesapeake Bay watershed: spatial patterns and effects on nitrate loads delivered to streams. JAWRA J. Am. Water Resour. Assoc. 2014, 50, 696-712. [CrossRef]

128. Mander, Ü.; Tournebize, J.; Tonderski, K.; Verhoeven, J.T.A.; Mitsch, W.J. Planning and establishment principles for constructed wetlands and riparian buffer zones in agricultural catchments. Ecol. Eng. 2017, 103, 296-300. [CrossRef]

129. Pearce, N.; Yates, A. Agricultural best management practice abundance and location does not influence stream ecosystem function or water quality in the summer season. Water 2015, 7, 6861-6876. [CrossRef]

130. Lawson, D.M.; Hall, K.R.; Yung, L.; Enquist, C.A. Building translational ecology communities of practice: insights from the field. Front. Ecol. Environ. 2017, 15, 569-577. [CrossRef]

131. David, M.B.; Flint, C.G.; Gentry, L.E.; Dolan, M.K.; Czapar, G.F.; Cooke, R.A.; Lavaire, T. Navigating the socio-bio-geo-chemistry and engineering of nitrogen management in two Illinois tile-drained watersheds. J. Environ. Qual. 2015, 44, 368-381. [CrossRef]

132. Beechie, T.; Pess, G.; Roni, P.; Giannico, G. Setting river restoration priorities: a review of approaches and a general protocol for identifying and prioritizing actions. N. Am. J. Fish. Manag. 2008, 28, 891-905. [CrossRef]

133. Bernhardt, E.S.; Palmer, M.A. River restoration: the fuzzy logic of repairing reaches to reverse catchment scale degradation. Ecol. Appl. 2011, 21, 1926-1931. [CrossRef]

134. Hermoso, V.; Pantus, F.; Olley, J.; Linke, S.; Mugodo, J.; Lea, P. Systematic planning for river rehabilitation: integrating multiple ecological and economic objectives in complex decisions: freshwater systematic rehabilitation planning. Freshw. Biol. 2012, 57, 1-9. [CrossRef]

135. Rhodes, H.M.; Closs, G.P.; Townsend, C.R. Stream ecosystem health outcomes of providing information to farmers and adoption of best management practices. J. Appl. Ecol. 2007, 44, 1106-1115. [CrossRef]

136. Hallett, L.M.; Morelli, T.L.; Gerber, L.R.; Moritz, M.A.; Schwartz, M.W.; Stephenson, N.L.; Tank, J.L.; Williamson, M.A.; Woodhouse, C.A. Navigating translational ecology: creating opportunities for scientist participation. Front. Ecol. Environ. 2017, 15, 578-586. [CrossRef]

137. Enquist, C.A.; Jackson, S.T.; Garfin, G.M.; Davis, F.W.; Gerber, L.R.; Littell, J.A.; Tank, J.L.; Terando, A.J.; Wall, T.U.; Halpern, B.; et al. Foundations of translational ecology. Front. Ecol. Environ. 2017, 15, 541-550. [CrossRef]

138. Winfield, I.J. Meeting across the river: from science to impact. Aquat. Conserv. Mar. Freshw. Ecosyst. 2010, 20, 607-610. [CrossRef]

139. Schilling, K.E.; Streeter, M.T.; St. Clair, M.; Meissen, J. Subsurface nutrient processing capacity in agricultural roadside ditches. Sci. Total Environ. 2018, 637, 470-479. [CrossRef]

(C) 2020 by the authors. Licensee MDPI, Basel, Switzerland. This article is an open access article distributed under the terms and conditions of the Creative Commons Attribution (CC BY) license (http://creativecommons.org/licenses/by/4.0/). 